\title{
染色物の摩擦堅牢度に及ぼすソーピングの効果
}

\author{
湘北短期大学生活科学科 菅 沼 恵子 \\ 慶応義塾大学理工学部 久 野洋
}

\section{THE EFFECT OF SOAPING ON THE RUBBING FASTNESS OF DYED FABRICS}

\author{
By Keiko Suganuma ${ }^{* 1}$ and Hiroshi Kuno ${ }^{* 2}$ \\ *1 (North Shore College, Nurumizu, Atsugi, Japan) \\ *2 (Faculty of Science and Technology, Keio University, \\ Hiyoshi, Yokohama, Japan)
}

Dry-rubbing tests on several dyes have been carried out and the effect of soaping on the rubfastness has been investigated from the kinetic viewpoint.

The removal process of dyes can be treated as a reversible reaction of first order. The amount of dye $(x)$ removed from dyed fabric to white cloth after $t$ times of rubbings can be expressed as

$$
x=[A /(1+1 / K)]\left[1-1 / e^{\left(k_{1}+k_{-1}\right) t}\right]+F
$$

where $A, k_{1}, k_{-1}, K$ and $F$ are initial dye content on dyed fabric, the rate constant of transfer of dye from dyed fabric to white cloth, the rate constant of reverse process of $k_{1}$, equilibrium constant and a constant indicating initial condition, respectively. Values of $F$ become small by soaping for vat or naphthol dyes and in many cases they become zero within an error range. The effects of soaping on the values of $x$ are represented by the kinetic properties. From these kinetic considerations, it has been concluded that soaping effect on the rub-fastness for vat and naphthol dyes is different from that for reactive dyes.

Linear relations have been obtained between $\ln K$ and the reciprocal of weights $(1 / W)$ on the white cloth. The slopes of the straight lines for all of the dyes are roughly equal and they are invariant by soaping.

Relations between $\ln k_{1}$ and $1 / W$ are roughly linear and the slopes of the straight lines for vat and naphthol dyes tend to become large by soaping.

(Received October 14, 1985)

\section{1. 緒言}

建染・ナフトール・反応染料では，沸騰石けん浴で染 色物のソーピング狆理を行う。ソーピングの勃果として は，较䧽表面に機械的に付着している染料を除去して， 洗濯・摩擦堅安度を高めることや、繊維内の染料の集合 状態に変化を与え，色調に良い影響を与えることなどが 知られている。 前回の実験 ${ }^{1)}$ によれば，洗濯堅军度はソーピングによ
って必ず向上しており，ソーピング時の染料の脱落量と 堅本性の間には，活は一定の関係线得られている。てれ に対し，摩擦堅审度はンーピングの条件によって買なり， ソーピング時の染料の脱落量とは一定の関係が得られな かった。そのため，摩擦堅安度にはかなり複雑な要因か 関与していると推測される。

一般に摩擦堅军度は，一定荷重のもとで一定回数摩擦 した後の白布の污染で評価されている。この方法でソー ピングの効果を検討する場合，摩擦堅审度試験の限られ 
た条件下での堅军性の良否を相対的に評洒し，得られた 結祭に対しては定性的な推論が導き出されるにすぎな

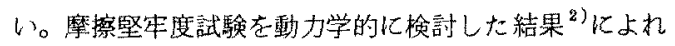
ば，染料の離脱過程は可逆一次反応徒う。また，染料 の摩擦堅军度汇打引る速度論的な特性は，染料加染色布 加ら添付白布任付着する時の速度定数 $k_{1}$ とその時の平 衡定数 $K$ にっって表すてとができる。こてで速度定数 $k_{1}$ 之平衡定数 $K$ は, 添付白布上に加加る荷重 $W$ と一定の関 係があり，時間的な変化之荷重の変化を含めて，摩擦堅 军度の特性をより定量的任泙洒する特性值となりうる。 また，摩擦堅军度に関しては，今日に至るまで基礎的な 考察がほとんどなされていないが，動力学的な解析に上 ってより基礎的な゙論議が期待できる。

そこで，数㮔の染料を用いて、ソーピング前後におけ る摩擦堅军度試験老行い，動力学的な観点加らンーピン グの効果を検討した。

\section{2. 理論}

摩擦に上る染料の離脱過程は，可逆一次反応に従い， その速度は(1)式で表さ扎る。

$$
-\frac{d(A-(x-F)]}{d t}=k_{1}(A-(x-F)]-k_{-1}(x-F)
$$

\section{$t$ : 摩擦回数}

$A ：$ 染色布の染着量

$k_{1}$ ：染料が染色布加ら添付白布へ移動する速度定 : 数

$k_{-1}$ : 染料が添付白布加染色布一戻る速度定数

$x$ ：摩擦回数 $t$ における添付白布上の染料量

$F: x-t$ 曲線の $t=0$ に打りる切片

ここで, $m=k_{1} A /\left(k_{1}+k_{-1}\right)$ とおいて（1）式を皘分 すれば(2)式加得られる。

$$
\ln \frac{m}{m-(x-F)}=\left(k_{1}+k_{-1}\right) t
$$

さらに(2)式変形して(3)式加得られる。

$$
\ln [m-(x-F)]=\ln m-\left(k_{1}+k_{-1}\right) t
$$

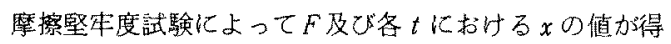
られる。(3)式に执て $\ln [m-(x-F)] は t$ は一次関 数であるから， $t$ と $\ln \{m-(x-F)\}$ と心直線回㷌化上 って傾き一( $\left(k_{1}+k_{-1}\right)$ を求好とができる。(3)式に よってー $\left(k_{1}+k_{-1}\right)$ の值を求めるためには $m$ が与えられ ていなければならない。しかし $m$ を解析的に決定するこ とは困難なので，試行錯誤法に上って $m$ を決定した。す なわち(3) 式の左辽のm任意の值を仅定して $\ln (m-$ $(x-F))$ と $t$ 上の直線回帰を行い，切片 $\ln m$ を求める。 とのmの值は一般に仮定した $m$ 之一致しないが, mの仮
定值老適当化変化させ，パーソナルコンピューターを用 いてての操作を絽り返すと，左辺の任意仮仮定したmと 切片 $\ln m$ 加ら得られた $m$ とが一致する とつ決定される。乙の時の傾きがー $\left(k_{1}+k_{-1}\right)$ であり， $k_{1}=(m / A) \cdot\left(k_{1}+k_{-1}\right)$ によって $k_{1}$ 老求好ると肪 できる。

また平衡定数 $K$ は定義によって $K=k_{1} / k_{-1}$ であるか ら $m, A$ 之次の関倸が成り立つ。

$$
m=\frac{A}{1+1 / K}
$$

平衡定数は(4)式によって与元られる。

\section{3. 実}

\section{験}

\section{1 染 色}

試料：綿唒金巾\#2023 (油化学協会) C. I. Vat Blue 12 の染色に用いた。

綿ブロード＃４0（中尾フィルター）その他の染料の染 色比用いた。

染料：次の染料を用いた。染料の選択基準は，抽出探 作娄含めて比色定量が比較的容易であるとと，各部属間 で染料の摩擦堅军度に大きな差がないとと，比較的术ピ ニラーに用いられているとと，色相は各部属と青青系， 赫系を一色ずつとりあげるなどを考虑して選択した。

建染染料 I：C. I.Vat Blue 12 (三井東王化学) 建染染料 II：C. I. Vat Violet 2 (三井東王化学) ナフトール染料 I：(誠和)

C. I. Azoic Coupling Component 2

C. I. Azoic Diazo Component 20

ナフトール染料 II：(誠和)

C. I. Azoic Coupling Component 2

C. I. Azoic Diazo Component 9

反店染料 I：C. I. Reactive Red 11 (日本化䒚) 反応染料 II：C. I. Reactive Blue 4（日本化薬） 染色方法

（1）建染染料 I，ナフトール染料 I， II，反応染料 I, 】は，前回 ${ }^{3)}$ と同様の方法で染色した。

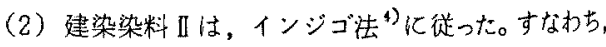
浴比 $10: 10$ 水に $35 \%$ 水酸化ナトリウム溶液を対溶洨 $2.5 \%$ ，ハイドロサルファイトを対溶洨 $2.3 \%$ 加え，さら に対織維 $4.2 \%$ の染料を加えて，75C亿加熱し這元浴を 作った。そして，浴比 $30: 1$ まで水を加えて染色し，染 色捘は (1) と同様江酸化水洗を行った。

\section{2 ソーピンク}

浴比 50:10水化 0.2\% の石けんを溶解し，80C以上 で30分間ソーピングを行った。その後洗濯㙨で1分間 2 回水洗し，脱水して自然乾燥した。 


\section{3 染着量の測定}

染色布及びソーピング布の染着量は，比色认よって求 めた。建染染料 I，四については，97\%濃硫酸に溶解し， それぞれ $815,685 \mathrm{~nm}$ に扔りる吸光度を溶解後直ちに 矵定した。ナフトール染料 I，【については，60大 加温 ピリジン腋で染料を抽出し，それぞれ $580 ， 530 \mathrm{~nm}$ にお ける吸光度を測定した。また反応染料 I，IIは，10\%酢 酸水溶液 90 Cで抽出し，それぞれ $550,595 \mathrm{~nm}$ におけ る吸光度を測定した。

\section{4 杽擦堅审度試験 (乾燥)}

学振型摩擦堅暒度試駼幾を用い, 糜摖用白綿布以は， \#40の綿ブロード $(5 \times 5 \mathrm{~cm})$ を用いた。染色布をタテ 方向《平行して長く，22×2.5 cmに切り，試験機にせ” 卜した。次江 $200 \mathrm{~g}$ の荷重を持つ摩擦子の先端江白綿布 をからせ，さらに0，50，100，200，400 g の分銅をの 世て、試駼片上 $10 \mathrm{~cm}$ 閒孝毎分 30 回の速さで 1〜200回 往復させた。測定は $20^{\circ} \mathrm{C} ， 65 \%$ の恒温恒湿内で行い, 同一条件で 5 回くり返し実験を行った。

\section{5 添付白布上に付着した染料の定量}

染料で活染された添付白布の反射率を平沼反射率計 SPR-3老用いて測定した。一枚の試験布につき污染部 を中央，上向き㯰き 4 か所測定した。このうちの適当 数の活染添付白布について, 染色布の染着量の定量と同 様の方法を用いて，染料を溶解または抽出し，10 mlの メスフラスコで調整して，染料付着量を比色によって求 め，反射率一濃度の検量線老求如た。 Kubelka-Munk の均一㹡散反射の理論によれば, 吸光度係数 $(K)$, 光の

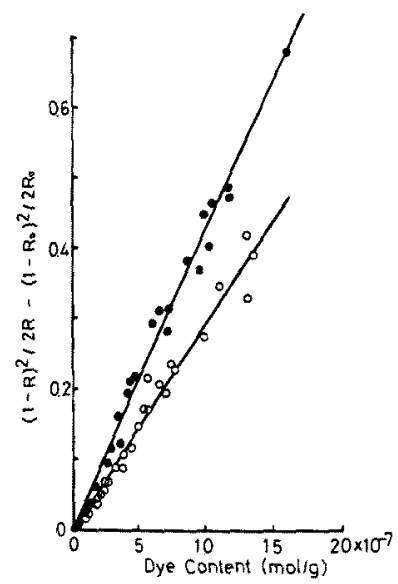

Fig. 1. Calibration curves of surface reflectancedye content for the staining white cloth with naphthol dye I.

$0:$ before soaping

: after soaping
散乱係数 $(\mathrm{S})$ ，表面反射率 $(R)$ との間には， $K / S=$ $(1-R)^{2} / 2 R$ 方成り立与，染色布の反射率索 $R$ ，未染布 (原布)の反射率を $R_{0}$ とした時, $f=(1-R)^{2} / 2 R$ 一 $\left(1-R_{0}\right)^{2} / 2 R_{0}$ の值は，染料濃度にはば比例することか

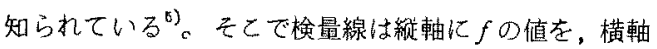
に染料濃度をプロットした。添付白付上に付着した染料 の量は，反射率を測定し，ての検量線を用いて求めた。

ナフトール染料Iの検量線を图1亿示した。染色布上 ソーピング布上では直線が異なり，建染染料 I，I，ナフ トール染料』についても，相異の程度化差はあるが，同 様の傾向が見られた。また，反忘染料比いて染色布 とソーピング布とは同一の直線が得られた。

\section{4. 結果及び考察}

\section{1 初期条件 $F$}

摩擦回数 $t$ に対して，添付白布に付着した染料量 $x$ を プロットした図を図2 2図5亿示した。 $F$ は $x-t$ 曲線 の $t=0$ に捕ける $x$ 如片の値である。各条件のッーピン グ前後汇おける $F$ 值と染色布の染料浱度 $A$ 之の比を表 1 亿示した。 $F / A$ 值が $1.00 \times 10^{-4}$ 以下は誤差範囲で 0上みなした。Fは荷重加增加するに従って大きくなる 傾向がある。また貄染・ナフトール染料では，末ンーピ ソグの場合 $F$ 值は存在するが, ソーピング後は低下し誤 差範囲内でほとんど0になるあのが多い。反応染料はり 一ピング前後で $F$ 值に変化は無く，はとんよ゙0である。 こ机らの結果から，Fはンーピングによって脱落する最 あ弱い力で布に付着している染料量であると推測され る。

4.2 添付白布への污染量 $\boldsymbol{x}$ とンービングの効果 ソーピングが $x-t$ 曲線に及结す効果は，染料によ二 て異なる。ナフトール染料 I（図2，図3）では，染料付 着量 $x$ がンーピングによって必ずしす低下するとは限ら ない。両者の付着量の大小関係活摩擦回数 $t$ 亿传存し， $t$ の小さい領域では未ソーピング布の方が付着量は大き いが，tの大きい領域では逆にソーピング布の方が高く なる。荷重 $600 \mathrm{~g}$ ではこの傾问は特に著しい。

これに対して建染染料1(図4，図5)では，与えられ た荷重の範囲で，xの值はソーピングによって必ず小さ くなる。建染染料 I, ナフトール染料 I , 反応染料 I, I についてあ同様の結果加得られた。特に反応染料 I, II はソーピングに上るxの低下が最す著しく、未ソーピン グの場合の約 $60 \%$ になった。

しかしソーピングによってある量の染料は脱落するか ら、ソーピング布の染着量は未ソーピング布より低下し ている。従来ンーピングによって摩擦堅安度が向上する と言われるのは、ソーピング時に脱落した染料量は無視 
Table 1. The ratio of amount of dye at $t=0$ to that of dye in the original fabric.

(1) before soaping

\begin{tabular}{|l|c|c|c|c|c|c|}
\hline \multicolumn{1}{|c|}{$\begin{array}{c}\text { rubbing } \\
\text { weight } \\
\text { Dye }\end{array}$} & 200 & 250 & 300 & 400 & 600 & Mean value \\
\hline Vat dye I & $4.74 \times 10^{-3}$ & $4.97 \times 10^{-8}$ & & $5.51 \times 10^{-3}$ & $5.76 \times 10^{-9}$ & $5.26 \times 10^{-8}$ \\
\hline Vat dye II & $6.54 \times 10^{-4}$ & $7.94 \times 10^{-4}$ & $8.44 \times 10^{-4}$ & $9.66 \times 10^{-4}$ & $1.09 \times 10^{-9}$ & $8.70 \times 10^{-4}$ \\
\hline Naphthol dye I & $2.19 \times 10^{-4}$ & $2.95 \times 10^{-4}$ & $3.91 \times 10^{-4}$ & $5.16 \times 10^{-4}$ & $6.32 \times 10^{-4}$ & $4.11 \times 10^{-4}$ \\
\hline Naphthol dye II & $1.33 \times 10^{-4}$ & $2.56 \times 10^{-4}$ & $1.45 \times 10^{-4}$ & $1.95 \times 10^{-4}$ & $5.59 \times 10^{-4}$ & $2.58 \times 10^{-4}$ \\
\hline Reactive dye I & 0 & & 0 & 0 & 0 & 0 \\
\hline Reactive dye II & 0 & $3.74 \times 10^{-4}$ & $2.64 \times 10^{-4}$ & $3.86 \times 10^{-4}$ & $4.34 \times 10^{-4}$ & $2.92 \times 10^{-4}$ \\
\hline
\end{tabular}

(2) after soaping

\begin{tabular}{|l|c|c|c|c|c|c|}
\hline \multicolumn{1}{|c|}{$\begin{array}{c}\text { rubbing } \\
\text { weight } \\
\text { Dye }\end{array}$} & 200 & 250 & 300 & 400 & 600 & Mean value \\
\hline Vat dye I & 0 & 0 & 0 & 0 & 0 & 0 \\
\hline Vat dye II & $4.88 \times 10^{-4}$ & $3.04 \times 10^{-4}$ & $4.26 \times 10^{-4}$ & $7.92 \times 10^{-4}$ & $8.12 \times 10^{-4}$ & $5.64 \times 10^{-4}$ \\
\hline Naphthol dye I & 0 & 0 & 0 & 0 & 0 & 0 \\
\hline Naphthol dye II & 0 & 0 & 0 & 0 & 0 & 0 \\
\hline Reactive dye I & 0 & & 0 & $1.08 \times 10^{-4}$ & $1.38 \times 10^{-4}$ & $6.2 \times 10^{-5}$ \\
\hline Reactive dye II & 0 & $1.42 \times 10^{-4}$ & 0 & $5.60 \times 10^{-4}$ & $6.93 \times 10^{-4}$ & $2.79 \times 10^{-4}$ \\
\hline
\end{tabular}

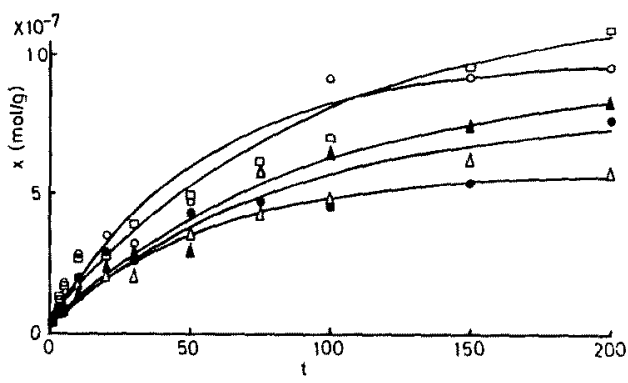

Fig. 2. Amount of dye $(x)$ removed by rubbing as a function of the number of rubbing time ( $t$ ) for naphthol dye I before soaping. Rubbing weight: $200 \mathrm{~g}(\triangle), 250 \mathrm{~g}(\bullet), 300 \mathrm{~g}$ $(\boldsymbol{A}), 400 \mathrm{~g}(\mathrm{O}), 600 \mathrm{~g}(\mathrm{\square})$. Dye content of dyed fabric is $7.77 \times 10^{-5} \mathrm{~mol} / \mathrm{g}$.

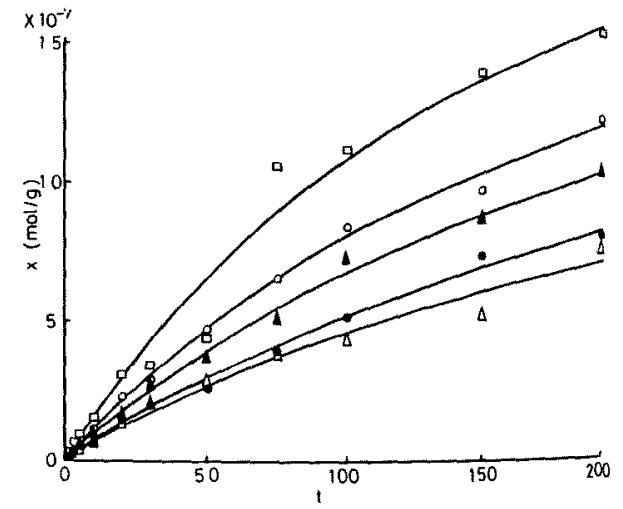

Fig. 3. Amount of dye $(x)$ removed by rubbing as a function of the number of rubbing time (t) for naphthol dye I after soaping. Symbols are the same as in Fig. 2. Dye content of dyed fabric is $6.87 \times 10^{-5} \mathrm{~mol} / \mathrm{g}$. 


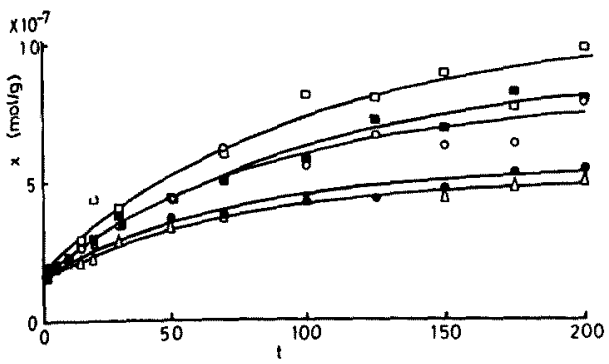

Fig. 4. Amount of dye $(x)$ removed by rubbing as a function of the number of rubbing time ( $t$ ) for vat dye I before soaping. Symbols are the same as in Fig. 2. except $500 \mathrm{~g}(\boldsymbol{a})$. Dye content of dyed fabric is $3.14 \times 10^{-5}$ $\mathrm{mol} / \mathrm{g}$.

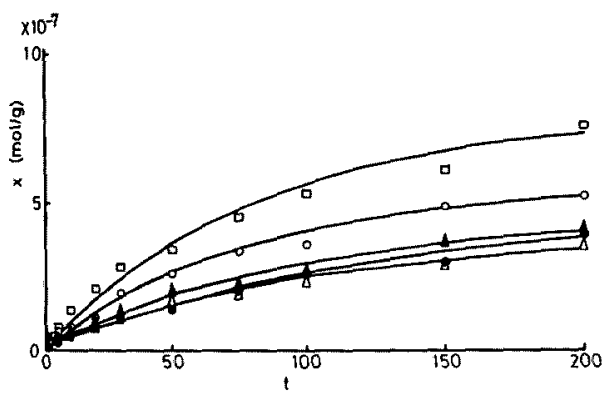

Fig. 5. Amount of dye $(x)$ removed by rubbing as a function of the number of rubbing time (t) for vat dye I after soaping. Symbols are the same as in Fig. 2. Dye content of dyed fabric is $2.90 \times 10^{-5} \mathrm{~mol} / \mathrm{g}$.

でるとして，添付白布の污染の程度をのみ比較して言 われてきたことと思われる。摩擦による染料の離脱過程 が一次反応化従うならば，污染量 $x$ は染色布の染料濃度 にはほ比例する。もこでンーピングによる真の效果は染 色布の染料漊度を $A$ とした時， $x / A-t$ 曲線によって与 えられる。图6に反応染料 I，荷重 $600 \mathrm{~g}$ の場合のンー ピング布及び末ンーピング布の $x-t$ 曲線を，また图 7 にそれそれの $x / \mathrm{A}-t$ 曲線を示した。その結果，反沁染 料の場合汇污染量 $x$ が低下するのは、ソーピングによる 染色布自身の濃度低下によるもので，朢军度の上暑は小 さいと之がわかる。建染染料 I， I，ナフトール染料 Iに 関して同様の炕理を試みた。前 2 者汇関しては， $x / A$ の俌はンーピング布の方が小さくなり，ソーピングの効

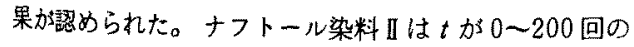
籁围内では $x / A$ の值はソーピング布の方がやや小さく なった。このように染料の污染量 $x$ は摩察回数及じ摩擦

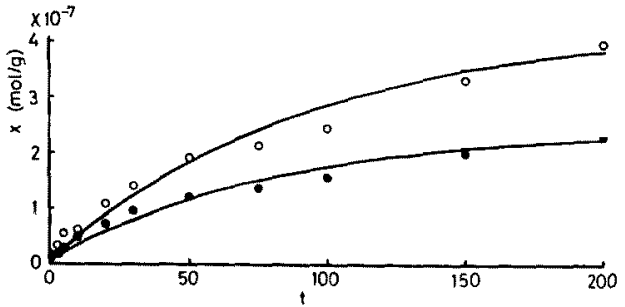

Fig. 6. Amount of dye $(x)$ removed by rubbing as a function of the number of rubbing time ( $t$ ) for reactive dye II with the rubbing weight $600 \mathrm{~g}$.

0 : before soaping

(Dye content $1.89 \times 10^{-5} \mathrm{~mol} / \mathrm{g}$ )

: after soaping

(Dye content $1.20 \times 10^{-5} \mathrm{~mol} / \mathrm{g}$ )

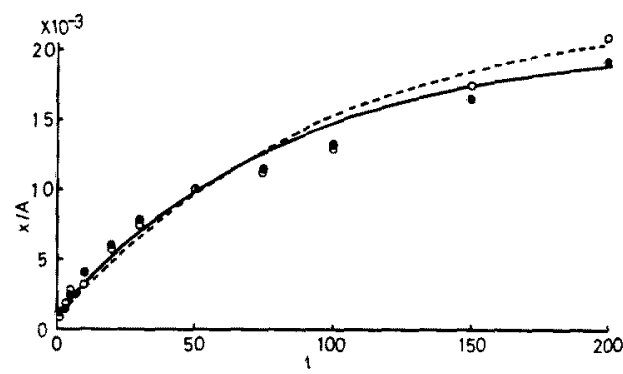

Fig. 7. The ratio $(x / A)$ of the amount of removed dye to that of dye in the original fabric with the number of rubbing time $(t)$ before $(0$, broken line) and after (, solid line) soaping for reactive dye 11 with the rubbing weight $600 \mathrm{~g}$.

子上の荷重に依存し，単純に一定回数，一定荷重のあと での値でソーピングの効果を比較することは困難である。 $x$ に及ぼすソーピングの効果は速度定数 $k_{-1}$ 及び平衡 定数Kを用いて評洒するととができる。本実験の結果を (3) 式に従って解析し，得られだ $m$ に関して $(x-F)$ )を $t$ に対してプロットした図を図8に示した。 本実験に用いた染料のすべてについて図80ような直線 関係力得られ, $\ln [m-(x-F)]$ と $t$ との相関係数は 0.9 以上で平均 0.98 であった。理詥式に従って得られた $k_{1}, k_{-1}$ の值を表 2 に示した。また平衡定数 $K$ は(4)式 によって与えられる。本実験で得られた結果によれば， $k_{1}, k_{-1}, K の オ ー タ ゙ ー は そ れ そ ゙ れ ~ 10^{-5} \sim 10^{-4}, 10^{-3} \sim$ $10^{-2}, 10^{-3} \sim 10^{-2}$ であるから，x/Aは次のように近做 できる。 

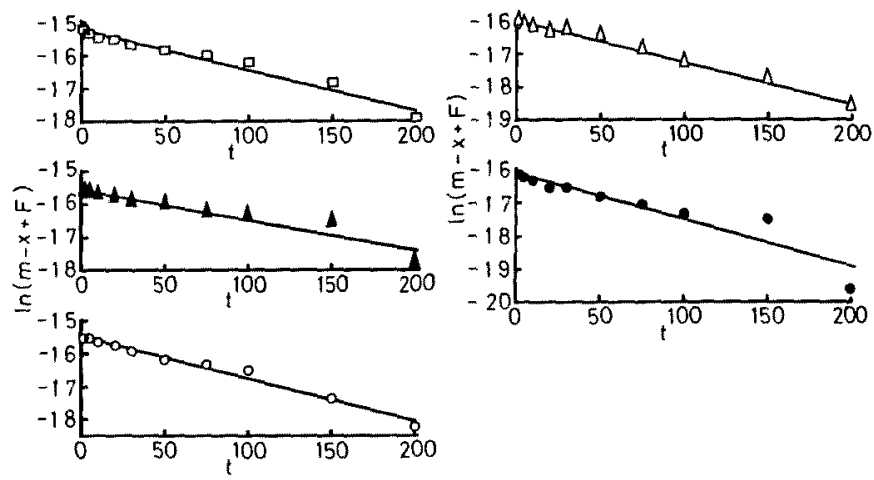

Fig. 8. The relation between $\ln [m-(x-F)]$ and $t$ for reactive dye II after soaping. Symbols are the same as in Fig. 2.

Table 2. The values of $m, k_{1}$, and $k_{-1}$ : Naphthol dye 1 , soaping

(Dye content $=6.87 \times 10^{-5} \mathrm{~mol} / \mathrm{g}$ )

\begin{tabular}{|c|c|c|c|}
\hline $\begin{array}{c}\text { rubbing } \\
\text { weight } \\
(\mathrm{g})\end{array}$ & $m$ & $k_{1}$ & $k_{-1}$ \\
\hline 200 & $9.741 \times 10^{-7}$ & $9.15 \times 10^{-6}$ & $6.35 \times 10^{-3}$ \\
\hline 250 & $1.228 \times 10^{-6}$ & $9.82 \times 10^{-8}$ & $5.40 \times 10^{-3}$ \\
\hline 300 & $1.411 \times 10^{-6}$ & $1.34 \times 10^{-4}$ & $6.38 \times 10^{-3}$ \\
\hline 400 & $1.563 \times 10^{-6}$ & $1.65 \times 10^{-4}$ & $7.08 \times 10^{-3}$ \\
\hline 600 & $1.914 \times 10^{-6}$ & $2.33 \times 10^{-4}$ & $8.15 \times 10^{-3}$ \\
\hline
\end{tabular}

$$
\frac{x}{A} \div K\left(1-\frac{1}{e^{k}-1 t}\right)+\frac{F}{A}
$$

(5)式加ら付着量 $x$ に及汪すソーピングの効果は，平衡

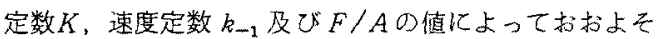
把握できるとよがわかる。

\section{3 速度定数 $k_{1}$ 及び平衡定数 $K$}

速度定数 $k_{1}$ は，染料加摩擦に上って染色布加ら添付白 布へ上移動する場合の速度定数である。前回の実験 ${ }^{2)}$ で, $k_{1}$ の自然対数は添付白布に加わる荷重Wの逆数之直線 関係にあることがわかっている。本実験に用いられた染 料について $\ln k_{1}-1 / W$ プロットを网9に示した。 $k_{1}$ の 值は建染染料，ナフトール染料では一般的に低荷重では 末ソーピング布よりソーピング布の方が小さいが，荷重 が大きなるに従って逆にンーピング有の力が大きな值 となる。染料によっては直線からのバラッキの大きい向 のもあるが，直線の傾きはン一ピング布の力が大きくな

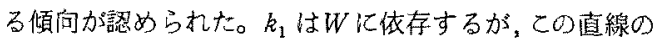
傾きと切片は染料国有の特性值となりうる。この埸合直 線の傾きは染料力離脱する場合のポテンシャル障壁と， また切片Sは染色布の表面状態などと関連があり，それ らがソーピング操作によって変化するのではないかと推

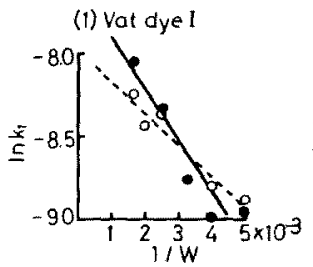

(2) Vat dye II
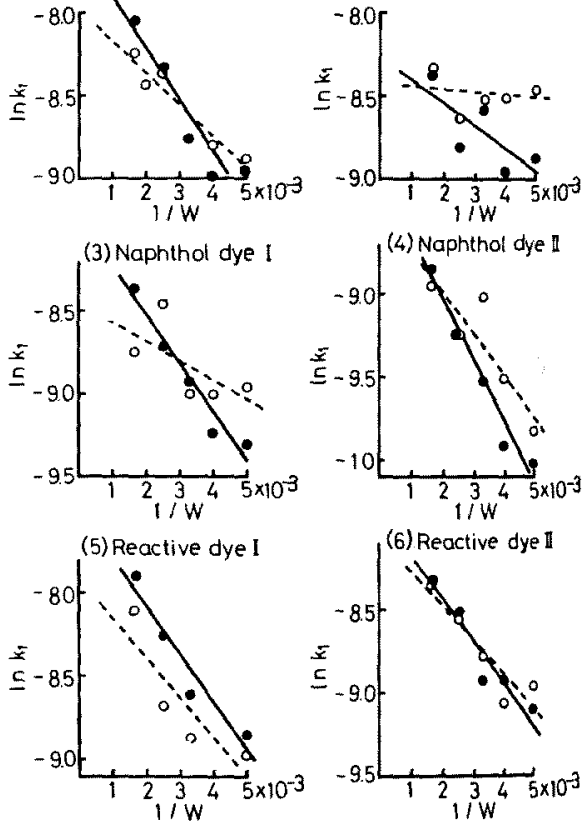

Fig. 9. The relation between the rate constant $k_{1}$ and the reciprocal of rubbing weight on the white cloth for dyeings before soaping ( $O$, broken line) and after soaping solid line).

測されるが，物理的意義の解釉についてはさらに詳絧な 研究を要するもの之思われる。

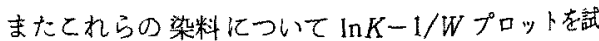
みた（図 10)。その結果得られた直線の傾きは、6種の 染料すべてについて類似した值を示し，しかあ同一の染 料に拁いては，未ソーピング布とンーピング布とで差か ほ上んど見られないよいう與味澡い結果走示している。 
(1) Vat dye 1

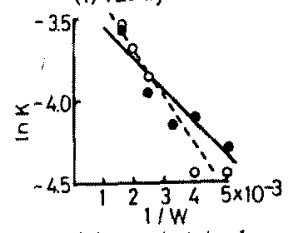

(3) Naphthol dye I

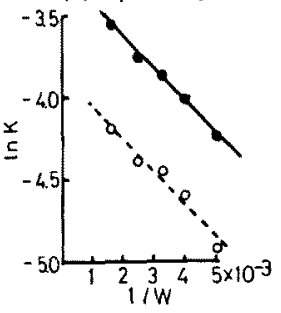

(5) Reactive dye II

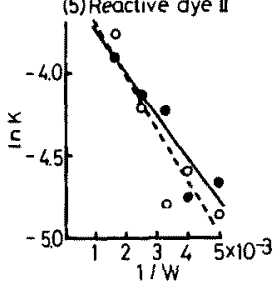

(2) vat dye 1

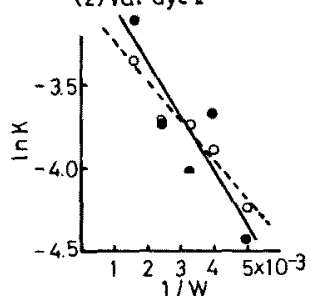

(4) Naphthol dye II

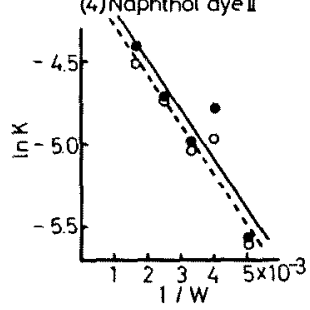

(6) Reactive dye I

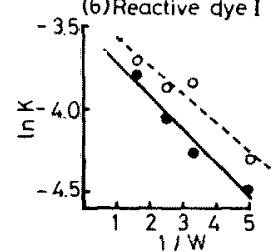

Fig. 10. The relation between equilibrium constant $K$ and the reciprocal of rubbing weight on the white cloth. Symbols are the same as in Fig. 9.

また切片の值は一般にソーピング布の方が低い值となっ たが、ナフトール染料では逆に高くなっている。

4.4 ソーピングによる染着状態の変化と摩擦堅 审度

本㥶験の結果は，建染・ナフトール染料と反応染料と では相異点が多い。たとえば，反射率一付着染料濃度の 検量線は前 2 者についてはンーピング前後で異なるのに 対して, 反応染料は变化がない。 $F$ 值についてす同様の

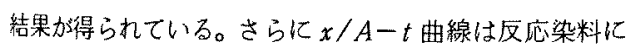
ついは与えられた条件下でンーピング前後の差がほよ んどないのに対し，建染・ナフトール染料では変化があ り，前者はソーピングによって低下するが，後者は增加 するすのがある。

建染・ナフトール染料ではソーピングによって瀻維の 表面付付着した染料が除去されるだけでなく，染料自身 加変化すると言われている日) ング前後での染料の結晶性の変化を結昆化の難搨によっ てろつのグループに分けている。また Sumnerら゙はり ーピングによる吸收スペクトル及び光二色性の変化に注 目し、ソーピング前後の染料の配问状態の違いる分類し， 十分なンーピング時間のもとでは，染料の配列は平行配

列加ら垂值配列に変化するあの加多いよ述へている。と のような帘化は反応染料では钼察されていない。さらに 建染・ナフトール染料戊不溶性であるのに対して反応染 料は水溶性である。そのため，建染・ナフトール染料では 染料の秛集・分散状態なども，ソーピング前後でかなり 珙なるものと思われる。とのようが諸観察より，上に述心 た摩察堅安度試験における相違は，染料の凝集・分散状 態・結晶性・配向性などの変化によるあの上推测される。

\section{5. 結}

\section{論}

数種の染料の摩摖堅阵度試験を行い，動力学的な観点 からンーピングの効果を調べた結果，次のととが明らか となった。

（1）摩摖による染料の離脱過程は，可逆一次反応に従 い，F值はナフトール，建染染料ではンーピングによ? て小さくなり，はとんどの場合 0 上なる。反応染料では ソーピング前後のFの值に変化は見られない。

（2）染料が摩擦によっで添付白布を污染する量 $x$ 亿及 ばすソーピングの効果は，速度定数 $k_{-1}$ ，平衡定数Kに よって評洒できる。ソーピングによって堅牛度は必ずし 向何上するとは爱えない。

（3）速度定数 $k_{1}$ について $\ln k_{1}-1 / W W^{\circ}$ ○ットの傾き はンーピング布の方が大きくなる㑯问を示した。また平 衡定数 $K$ に関して， $\ln K-1 / W$ プロットから得られる直 線の傾きは，ソーピング前後でほよんど差がなく，また， 染料の種類に毛依存しなかった。

(4) 摩擦堅安度に及ばすソーピングの効果は, 建染・ナ フトール染料と反応染料之では異なっており，前2者につ いては、ソーピングによる付着染料及び染料の染着状態 に質的な変化が推察されるが, 後者については，摩擦堅 牛度 (乾燥)に関する限り質的な变化仕考えられない。

染料をご提供いただきました三井東圧化学(株)ならで に日本化蒋(株)に感謝致します。

\section{文献}

1) 管沼恵子，家政誌，32，432（1981）

2) Keiko Suganuma and Hiroshi Kuno; J.S.D.C., 102, 100 (1986)

3）菅沼恵子，家政誌，34，427（1983）

4) 近藤一夫，「染色の科学」，建帛社，p.234 (1978)

5）中垣正幸螎，「被服整理学実馱堷」，光生館，p.156 (1976)

6) 黒木宣彦、「染色理論化学」, 楨畫店, p.220 (1973)

7) H. H. Sumner, T. Vickerstaff and E. Waters; J.S.D.C., 69, 181 (1953) 